\title{
Test Anxiety and Selected Personal Factors as Determinants of Academic Performance of Undergraduate Online Learners
}

\author{
Margaret J. Suarez ${ }^{1 *}$ and Maria Ana T. Quimbo² \\ ${ }^{1}$ Faculty of Information and Communication Studies \\ University of the Philippines Open University \\ ${ }^{2}$ College of Public Affairs and Development \\ University of the Philippines Los Banos \\ *margaret.jarmin@upou.edu.ph,meg.jarmin@gmail.com
}

Published online: 27 December 2016

To cite this article: Suarez, M. J. and M. A. T. Quimbo. 2016. Test anxiety and selected personal factors as determinants of academic performance of undergraduate online learners. Malaysian Journal of Distance Education 18(1): 29-51. http://dx.doi.org/10.21315/ mjde2016.18.1.3

To link to this article: http://dx.doi.org/10.21315/mjde2016.18.1.3

\begin{abstract}
Test anxiety is a prevalent problem that can handicap a student's ability to perform well academically. This problem has been said to affect nearly $35 \%$ of the college student population in the United States. In the Philippines, there is a dearth of literature on test anxiety and its effect of academic performance particularly among distance learners. This study was an attempt to thicken the discourse on the said issue. This paper analysed the relationship of selected personal factors and test anxiety with academic performance of online learners under the Bachelor of Arts in Multimedia Studies, a degree program offered by the Faculty of Information and Communication Studies of the University of the Philippines Open University. The selected personal factors of online learners considered in the study include gender, age and classification. Respondents were randomly selected students of the Bachelor of Arts in Multimedia Studies program enrolled during the Academic Year 2013-2014. Self-administered survey questionnaire was used in the data collection which included the Westside Test Anxiety Scale to measure the level of students' test anxiety. Data on selected personal factors of students such as gender, age and classification as well as their General Weighted Average were collected from the Faculty database. Appropriate statistical tools were employed to address the research objectives. Results of the study served as the basis in identifying learner support programs and
\end{abstract}


strategies to help undergraduate online learners succeed and complete their degree program and eventually be successful lifelong learners.

Keywords: test anxiety, academic performance, online learners, student support

\section{Introduction}

Tests and examinations at all levels in the education ladder especially in higher education have been considered an important and powerful tool for decision making in our society, with people of all ages being evaluated with respect to their achievement, skills and abilities (Rana and Mahmood, 2010). According to Zoller and Ben-Chain (1990), 'the era in which we live is a test-conscious age in which the lives of many people are not only greatly influenced, but are also determined by their test performance' (Rana and Mahmood, 2010).

One major function of testing is to direct instruction, measure learner achievement and thus to contribute to the evaluation of learning progress and outcomes. Tests may be viewed either as a deterrent or as a motivator that stimulate learning. Largely though, test results are used to provide evidences in making objective decision-making. It is, therefore, important that tests are properly designed and well-thought out in order to minimise if not eliminate bias in executing value judgements and making effective decision-making.

\section{Objectives of the Study}

The main objective of the study is to analyse the relationship of test anxiety and selected personal factors with academic performance of Bachelor of Arts in Multimedia Studies (BAMS) online learners of the University of the Philippines Open University (UPOU). The specific objectives are as follows:

1. To describe the profile of UPOU BAMS online learners

2. To determine the level of test anxiety and academic performance of BAMS online learners who are enrolled in the First, Second and Third Terms of the Academic Year 2013-2014 
3. To analyse the relationship of selected personal factors and level of test anxiety of BAMS online learners with their academic performance and

4. To recommend learner support programs or strategies that UP Open University can provide to help students succeed in their studies

\section{Review of Related Literature}

\section{The Distance Learner Profile}

A careful literature review of early description of distance learner was presented by Kaye (1981). His description is based on the evidence drawn by ten distance learning universities in the world. The 10 universities are:

1. Open University in Britain

2. Allama Iqbal Open University in Pakistan

3. Athabasca University in Canada

4. Everyman's University in Israel

5. Fernuniversität in Germany

6. Free University in Iran

7. Sri Lanka Institute of Distance Education

8. Universidad Estatal a Distancia in Costa Rica

9. Universidad Nacional Abierta in Venezuela

10. Universidad Nacional de Education a Distancia in Spain

Kaye summarised the common characteristics of the distance learners of the 10 universities. These are adults with ages range from 20 to 40 years old, most students study at a part-time basis, predominantly male population, home-based, highly motivated, not privileged socially, predominantly urban, and with a wide variety of educational backgrounds (Kaye, 1981).

On the other hand, Moore and Kearsley (1996) presented three common features of a distance learner. According to Moore and Kearsley, distance learners are remarkably motivated, highly focused on what tasks must be completed, and are forced to study in an environment less favorable to education. In another study by Biner et al. (1996), it was found that students in distance education programs tended to be 'more intelligent, emotionally stable, trusting, compulsive, passive and conforming' than traditional students. 
A number of studies were also conducted that determined the reasons why a person enrolls in a distance education program. Rangecroft et al. (1999) established that among the factors important for distance learners include professional development, course content, personal development, and widening career opportunities.

Furthermore, a study by Alip (2002) cited that distance learners are looking for the following learning components: 1) real-time and timedelayed options; 2) well-designed, engaging, and intellectually challenging courses; 3) seamless, available, and reliable delivery technology; 4) greater emphasis on learner-centered versus teacher-centered approaches; 5) a high level of interaction including problem-based simulations; 6) modularised formats instead of courses demanding large chunk of time; 7) participation in a learning community through interaction with instructors and fellow students; and 8) academic advising and student support services which are convenient and easy to understand and access.

The Beginnings of Distance Education in the University of the Philippines Open University

The roots of distance education in the University of the Philippines can be traced back to the 'Paaralang Panghimpapawid' or the School-on-theAir of Radyo DZLB which was operated by the UP Los Banos Institute of Development Communication, then under the College of Agriculture. This program aimed at reaching the rural families, particularly the farmers, to teach them modern farming techniques. This was followed by the development of a program to upgrade science and mathematics teachers in the country through distance education. The program was called Science Teaching Using Distance Instruction (STUDI) which gave rise to the Diploma in Science Teaching Program, the first degree program offered by the University of the Philippines Open University (UPOU) in the distance mode (Bandalaria, 2001). Recognising the perennial challenge of providing quality higher education to a growing population, the UP Board of Regents, through a board resolution, approved the establishment of the UP Open University (UPOU) in its 1084th meeting on 23 February 1995.

The UPOU seeks to provide wider access to a quality higher education and adhere to the highest standards of academic excellence. It aims to guarantee 
academic freedom and encourage social responsibility and nationalistic commitment among its faculty, staff and students (Bandalaria, 2001). Specifically, UPOU aims to:

1. provide opportunities for alternative access to quality higher education by offering baccalaureate and post baccalaureate degree programs and non-formal courses by distance education;

2. develop a system of continuing education for sustaining professional growth and improving technical skills especially for those who cannot leave their jobs or homes for full-time studies; and

3. contribute towards upgrading the quality of residential instruction in the university and the educational system of the country, in general, by developing, testing, and utilising innovative instructional materials and technology and sharing these with other colleges and universities through co-operative programs.

Currently, UPOU offers the following programs delivered in the distance mode: Associate in Arts (AA), Bachelor of Arts in Multimedia Studies (BAMS), Bachelor of Education Studies (BES), Diploma in Computer Science (DCS), Diploma in Science Teaching (DST), Diploma in Mathematics Teaching (DMT), Diploma/Master of Arts in Language and Literacy Education (D/MLLE), Diploma/Master of Arts in Social Studies Education (D/MSSE), Graduate Certificate in ASEAN Studies, Diploma/ Master in International Health (D/MIH), Diploma/Master in Land Valuation \& Management (D/MLVM), Diploma/Master in Social Work (D/MSW), Diploma in Research and Development Management (DR\&DM), Master of Development Communication (MDC), Master of Distance Education (MDE), Master of ASEAN Studies, Master of Arts in Nursing (MAN), Master of Public Management (MPM), Master of Environment and Natural Resources Management (MENRM), Master of Information Systems (MIS), Doctor of Philosophy in Education (Biology Education, Chemistry Education, Physics Education, Mathematics Education), and Doctor of Communication (DComm) (UP Open University website).

The UPOU also offers non-formal courses such as Professional Teaching Certification Program, Understanding the Convention on the Rights of the Child, Community Mental Health, Caring for Children with Special Needs, Health Research: Methods, Ethics and Uses, Introduction to 
e-Commerce, New Enterprise Planning, Organic Agriculture, Personal Entrepreneurial Development, Simplified Accounting for Entrepreneurs (SAFE), Responding to Climate Risks in Agriculture and Natural Resources Management (RCRANRM) and Satoyama Online (Living in Harmony with Nature).

The UPOU operates seven Learning Centers located in strategic areas of the country. These Centers are the venues where students can conduct and seek advice on the following transactions, activities and procedures: application for admission, registration student orientation, distribution of course materials, dropping of subjects, filing leave of absence, venue for examinations, accessing library materials, face-to-face tutorials (if available), and tutorials on basic computer and internet literacy. Learning Centers are mostly located in other UP campuses and state universities in selected regions of the country. To serve the student support needs of offshore students, the University has created the Virtual Learning Center, where all transactions and procedures are conducted and communicated online.

\section{The Bachelor of Arts in Multimedia Studies Program}

In a 2005 survey conducted among UPOU Associate in Arts (AA) students, eight out of ten respondents expressed interest in pursuing a baccalaureate degree in multimedia studies after completing their AA program. On the basis of this survey, UPOU estimates 70 to 100 new entrants to the BAMS program per year or an average of 380 enrollees per year beginning its fourth year of offering. Currently, no other unit in the University of the Philippines System offers a baccalaureate program in multimedia studies. Among the major universities in the Philippines, only the De La Salle University College of St. Benilde offers a similar program, although the curriculum overly emphasises technology courses at the expense of the social development context. Furthermore, other related programs currently being offered by Philippine institutions of higher learning may be classified under three main categories: information technology, library science, and communication science. It may be noted that these three disciplines, in fact, share similar if not identical roots. The current perspective views a convergence of these disciplines that presents a coherent set of skills, competencies, and values that is appropriate for a professional within the global knowledge economy. 
The Bachelor of Arts in Multimedia Studies is founded on this convergence of disciplines (BAMS program proposal, 2007).

During the 27th meeting of the UP Open University Council held on 15 August 2007, the institution of the BAMS program was approved and consequently approved by the Board of Regents (BOR) of the University of the Philippines System during its 1223rd meeting held on 22 August 2007. The BAMS program is composed of 15 General Education (GE) courses (45 units), 18 major courses (54 units), six residential multimedia production courses (18 units), five electives (15 units), PI 100 (3 units), a three-unit special topics, and a six-unit special project for a total of 144 academic units. Students must complete eight units of Physical Education (PE) courses and six units of courses offered in the National Service Training Program (BAMS program proposal, 2007).

The BAMS graduates are expected to be knowledgeable with the range and use of multimedia information and communication technologies; articulate in philosophical and theoretical underpinnings of developments in the field and their social implications; abreast of emerging trends, protocols procedures, and their implications on practice; proficient in hardware operation, software development, and applications use; able to produce multimedia knowledge products; able to contribute to the body of research on multimedia theories and processes; and able to contribute to local multimedia initiatives in the context of global realities.

\section{Test Anxiety and Academic Performance}

Test anxiety is a prevalent issue that affects nearly $35 \%$ of the college student population. Specifically, about $18 \%$ are handicapped by high test anxiety and an additional $16 \%$ are handicapped by moderately high test anxiety (Driscoll, Holt and Hunter, 2005). These highly anxious students scored about 12 percentile points lower than those with low anxiety, making test anxiety one of the most serious academic handicaps among students today (Hembree, 1988). Meanwhile, Hill and Wigfield (1984) as cited by Chapell et al. (2005) extrapolated from the literature and estimated that about $25 \%$ of American primary and secondary school students or about 10 million students, suffered lower academic performance due to test anxiety. 
Test anxiety is thought to have two components: (1) a worry or cognitive component, and (2) an emotionality component. The worry component refers to student's negative thoughts that disrupt performance, while the emotionality component refers to affective and physiological arousal aspects of anxiety (Bonito, 2013).

Studies revealed that high test anxiety individuals respond to testing situations with high levels of emotionality that triggers worrying, characterising both emotionality and worry as components that decrease performance (Wong, undated).

Moreover, Wine (1971) proposed a cognitive attention theory that explained how test anxiety affects performance. He opined that individuals with test anxiety divide their attention between task relevant activities and preoccupations with worry and self-criticism. Such preoccupations leave less attention for task-directed efforts, causing a hindrance in performance. Most importantly, findings from past studies have indicated that highly anxious individuals perform poorly, especially when the task is hard or when performance is evaluated. During exams, these individuals are likely to engage in negative, self-deprecatory thoughts about themselves and about test consequences (Lee, 1999). According to Dutke and Stober (2001), these thoughts partially occupy the working memory, restricting both storage and processing capacity, which explains many of the 'blank-outs' students report during exams (Wong, undated).

In other studies, Khalid and Hasan (2009) conducted a study with selected sample of 187 undergraduate students to explore the relationship between test anxiety and academic achievement and found that students with high academic achievement have low test anxiety scores and vice versa. Additionally, Chapell et al. (2005), test anxiety has been identified by many under graduate and graduate students as an important problem they want to help in dealing with. The result of the large scale study helps provide a clearer picture in the reductions of grade point average (GPA) associated with high, moderate and low test anxiety found in undergraduate and graduate students. The fairly small effect sizes and differences in GPA related to test anxiety in the study suggested that test anxiety is just one of the many factors influencing undergraduate and graduate students. There is 
significant but small inverse relationship between test anxiety and GPA in both undergraduate and graduate students.

Several studies explored gender differences with respect to test anxiety and found that female students have higher test anxiety than male students (Chapell et al. 2005). Cassady and Johnson (2002) explained 'that one explanation for differences in test anxiety on the basis of students' gender is that males and females feel the same levels of test worry, but females have higher levels of emotionality'. Zeidner (1990) concluded that difference in test anxiety scores of male and female is due to gender difference rather than scholastic ability (Rana and Mahmood, 2010).

\section{Conceptual Framework}

Two major variables were considered in the study. These are the online learner profile and the online learner academic performance (Figure 1). The learner's profile was determined using selected personal factors such as age, gender and classification and the level of test anxiety. On the other hand, the learner's academic performance was measured in terms of the general weighted average grade for all subjects taken during the academic year 2013-2014. Figure 1 also shows that the results of the analysis of the relationships between variables should provide inputs to learner support programs or strategies that the UP Open University can provide to help its online learners succeed in their studies.

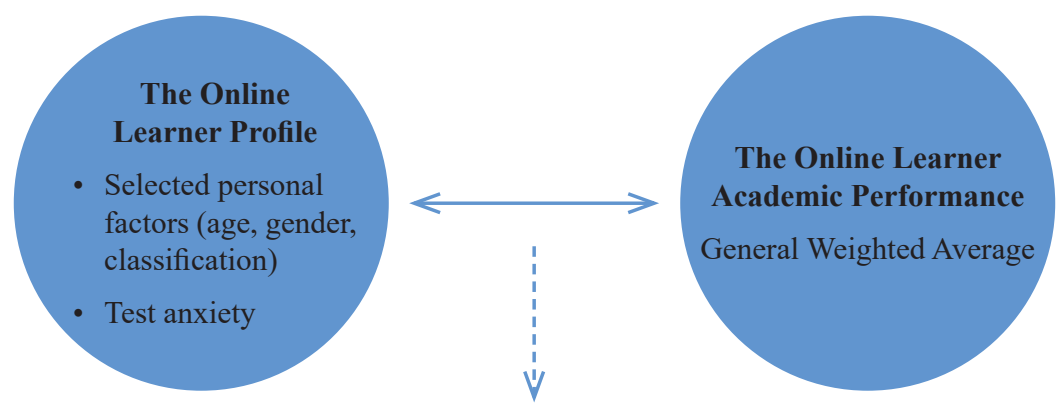

Learner Support Program and Strategies

Figure 1 Conceptual framework showing the relationships between entities of the study 


\section{Definition of Key Terms}

Academic performance - refers to the general weighted average (GWA) of BAMS students for all subjects taken during the school year 2013-2014. The grading system being used by the UP Open University is as follows:

1. 1.00-1.25: Excellent

2. 1.50-1.75: Very Good

3. 2.00-2.25: Good

4. 2.50-2.75: Satisfactory

5. 3.00: Passed

6. 4.00: Conditional

7. 5.00: Failed

Age - refers to number of years the respondent has lived

Classification-refers to the current academic standing of the student defined as Freshman, Sophomore, Junior, and Senior

Gender — refers to being male or female of the respondent

Test - refers to unit exams such as midterm and final exams (written, computer-based exams) and other types of summative assessment tools such as term paper, project, portfolio and practicum/internship.

Test anxiety-refers to the score in the Westside Test Anxiety Scale by Driscoll (2004). It provides a score that determines six anxiety levels, namely:

1. 1.0-1.9: Comfortably low test anxiety

2. 2.0-2.5: Normal or average test anxiety

3. 2.6-2.9: High normal test anxiety

4. 3.0-3.4: Moderately high anxiety

5. 3.5-3.9: High test anxiety

6. 4.0-5.0: Extremely high anxiety 


\section{Methodology}

A total of 58 randomly selected BAMS students enrolled in the First, Second and Third terms of the Academic Year 2013-2014 served as respondents of the study. The study utilised the Westside Test Anxiety Scale by Driscoll (2004) to measure test anxiety of the BAMS student-respondents using a survey questionnaire. The Westside Test Anxiety Scale is a brief ten-item instrument that covers self-assessed anxiety impairment and cognitions which can impair performance. Additionally, it combines six items assessing impairment, four items on worry and dread, and no item on physiological over-arousal. According to the American Test Anxieties Association, several researchers have used the instrument in colleges, training programs and ongoing researches and projects. Driscoll (2004) added that said instrument was important in informing school programs intended to reduce test-anxiety impairments by identifying those students who might benefit from an anxiety-reduction program. As designed, this instrument is deemed useful for many online learners who suffer from learning anxiety due to their physical separation in time and space from their teachers and fellow students.

The profile of the student-respondents was described and presented using frequency table and mean. Relational tool such as the Pearson Product Moment Correlation was employed to determine the relationships between selected factors, namely, age, test anxiety and academic performance of distance learners. Likewise, tests of mean differences such as $t$-test and Analysis of Variance were utilised to find out whether significant differences in test anxiety levels and academic performance across gender and classification exist.

\section{Results and Discussion}

\section{Profile of BAMS Online Learners}

The profile of BAMS online learners was described using selected personal factors such as age, gender and classification. The youngest respondent of the study was 16 years old while the oldest was 58 . The respondent's mean age was 27.7 years old. The greater percentage $(52 \%)$ of the respondents belonged to the 16-25 age bracket. More than one third (36\%) fell within 
the 26-35 age group while three (5\%) were between 36 and 45 years old. The remaining $7 \%$ were aged above 46 years old (Figure 2). These findings support the studies of Qureshi, Morton and Antosz (2002) stating that more than $42 \%$ of distance education students are in the 20 to 24 age bracket. Moreover, in a study by Park (2007), it was noted that most distance education students are adults between 25 to 59 years old. Conversely, Boston, Ice and Gibson (2012) indicated that older undergraduates enrolled in distance education programs are relatively more than their younger counterparts.
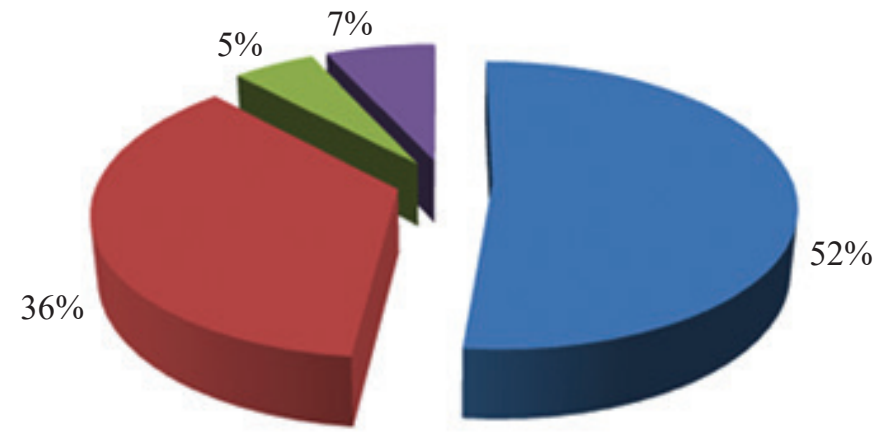

=16-25

= $26-35$

= $36-45$

= 46-above

Figure 2 Distribution of respondents by age group

By gender, 23 respondents $(40 \%)$ were males while $35(60 \%)$ were females (Figure 3). The greater number of female distance learners is not surprising. According to the study of WPI Academic Technology Centre (2012), most distance students are predominantly female, with different studies indicating that between $60 \%$ and $77 \%$ of students are female. Additionally, in a study of Flor et al. (2009), there is a consistent higher number of female enrollees than male enrollees in UP Open University from 1995 to 2005. Hence, the presence of more females was apparent in the program.

By classification or year level, most respondents (31\%) were Sophomore students (Figure 4). This result shows a positive outcome in the program implying that more students persisted to continue their studies after their first year in the program. Meanwhile, $26 \%$ of the respondents were in their Freshman year, 22\% were Senior, and 21\% were Junior BAMS students. The reason for the decreasing number of enrollees as they go through the BAMS program is an area worth investigating for future research. 


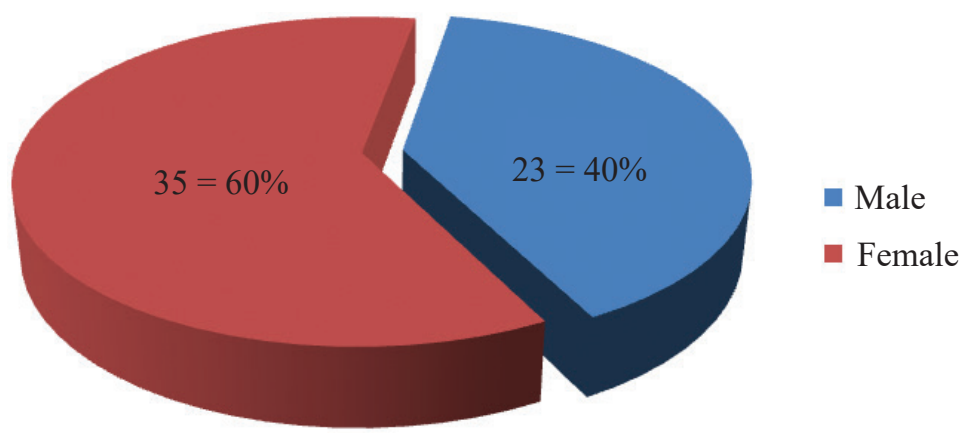

Figure 3 Distribution of respondents by gender

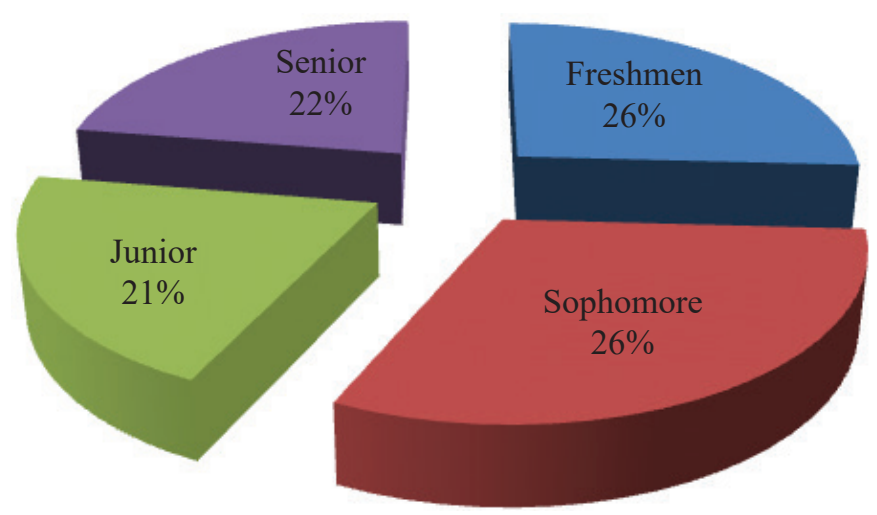

Figure 4 Distribution of respondents by classification

The description of the BAMS online learners using the selected personal factors is summarised in Table 1. The results show that the BAMS online learners are generally young, female and in the Sophomore classification level in their studies.

\section{Selected Personal Factors and Test Anxiety Level of BAMS Online Learners}

Test anxiety level was analysed between and across the selected personal factors of student-respondents. Tables 2 to 4 present the frequency and percentage (in parenthesis) distribution values across the levels of the selected variables. By age group, majority of those who belonged to the youngest age group of 16 to 25 years are within the 'normal or average test anxiety' level (33.3\%) followed by those falling within the 'comfortably low 
Table 1 Selected personal factors of BAMS online learners

\begin{tabular}{lcc}
\hline Selected Personal Factors & Number & Percent \\
\hline Age (years) & 30 & \\
$16-25$ & 21 & 52 \\
$26-35$ & 3 & 36 \\
$36-45$ & 4 & 5 \\
46 and above & & 7 \\
Gender & 23 & \\
Male & 35 & 40 \\
Female & & 60 \\
Classification & 15 & \\
Freshman & 18 & 26 \\
Sophomore & 12 & 31 \\
Junior & 13 & 21 \\
Senior & & \\
\hline
\end{tabular}

test anxiety' level (23.3\%) (Table 2). Meanwhile, most of the next older group of students of 26 to 35 years was also observed to have either 'comfortably low test anxiety' level $(38.1 \%)$ or 'normal or average test anxiety' level (38.1\%). Meanwhile, more students within the younger age groups are also obtained high scores in the test anxiety scale implying high test anxiety level. Overall, these results imply that older students appear to have greater level of confidence when taking a test. Further examination of these results using Analysis of Variance, however, revealed that the difference in test anxiety level across age groups was not significant $(F=1.881 ; p=0.144)$ which indicates similarity in anxiety level among online learners regardless of age.

By gender, results showed that most females (37.1\%) have 'comfortably low test anxiety' level followed closely $(34.3 \%)$ by those within the 'normal or average test anxiety' level (Table 3). Among males, on the other hand, the majority (30.4\%) belongs to the 'normal or average test anxiety' category. This was followed by those that fall within the 'comfortably low test anxiety' level (26.1\%) and 'high normal or average test anxiety' level (21.7\%). These results imply that female BAMS distance learners exhibit lower test anxiety level compared to male BAMS distance learners. This is in contrast with the results of Chapell et al. (2005) which revealed that female students 
Table 2 Anxiety level by age group

\begin{tabular}{lccccc}
\hline Anxiety Level & $\begin{array}{c}16-25 \\
\text { years }\end{array}$ & $\begin{array}{c}26-35 \\
\text { years }\end{array}$ & $\begin{array}{c}36-45 \\
\text { years }\end{array}$ & $\begin{array}{c}46 \text { and } \\
\text { above }\end{array}$ & Total \\
\hline 1.0-1.9: Comfortably low test anxiety & 7 & 8 & 2 & 2 & 19 \\
& $(23.3)$ & $(38.1)$ & $(66.7)$ & $(50.0)$ & $(32.8)$ \\
2.0-2.5: Normal or average test anxiety & 10 & 8 & - & 1 & 19 \\
& $(33.3)$ & $(38.1)$ & & $(25.0)$ & $(32.8)$ \\
2.6-2.9: High normal test anxiety & 4 & 2 & 1 & - & 7 \\
& $(13.3)$ & $(9.5)$ & $(33.3)$ & & $(12.1)$ \\
3.0-3.4: Moderately high anxiety & 3 & 2 & - & 1 & 6 \\
& $(10.0)$ & $(9.5)$ & & $(25.0)$ & $(10.3)$ \\
3.5-3.9: High test anxiety & 4 & 1 & - & - & 5 \\
& $(13.3)$ & $(4.8)$ & & & $(8.6)$ \\
4.0-5.0: Extremely high anxiety & 2 & - & - & - & 2 \\
& $(6.7)$ & & & & $(3.4)$ \\
\hline Total & 30 & 21 & 3 & 4 & 58 \\
& $(100.0)$ & $(100.0)$ & $(100.0)$ & $(100.0)$ & $(100.0)$ \\
\hline
\end{tabular}

Table 3 Anxiety level by gender

\begin{tabular}{lccc}
\hline Anxiety Level & Female & Male & Total \\
\hline 1.0-1.9: Comfortably low test anxiety & 13 & 6 & 19 \\
& $(37.1)$ & $(26.1)$ & $(32.8)$ \\
2.0-2.5: Normal or average test anxiety & 12 & 7 & 19 \\
& $(34.3)$ & $(30.4)$ & $(32.8)$ \\
2.6-2.9: High normal test anxiety & 2 & 5 & 7 \\
& $(5.7)$ & $(21.7)$ & $(12.1)$ \\
3.0-3.4: Moderately high anxiety & 3 & 3 & 6 \\
& $(8.6)$ & $(13.0)$ & $(10.3)$ \\
3.5-3.9: High test anxiety & 4 & 1 & 5 \\
& $(11.4)$ & $(4.3)$ & $(8.6)$ \\
4.0-5.0: Extremely high anxiety & 1 & 1 & 2 \\
& $(2.9)$ & $(4.3)$ & $(3.4)$ \\
\hline Total & 35 & 23 & 58 \\
& $(100.0)$ & $(100.0)$ & $(100.0)$ \\
\hline
\end{tabular}


have higher test anxiety than male students. Further analysis using $t$-test, however, showed that the difference in test anxiety level by gender was not significant $(t=0.452 ; p=0.652)$ implying similarity in anxiety level across gender groups.

Across classification or year level of students, results showed that the greatest percentage of Seniors (46.2\%) and Freshmen (40\%) have 'comfortably low test anxiety' level (Table 4). Among Sophomores, the majority are within the 'normal or average test anxiety' level (50\%). Meanwhile for the Juniors, an equal number fall within the 'comfortably low test anxiety' level (33.3\%) and the 'normal or average test anxiety' level (33.3\%). It should also be noted that two Freshmen students have been found in the 'extremely high anxiety' level. Fewer number of students can be found in the other categories or test anxiety levels. Overall, these results imply that the Seniors or those who have longer experience as distance learners exhibit lower test anxiety level compared with the rest of the students. Further analysis using Analysis of Variance, however, showed that the difference in test anxiety level across student classification or year level was also not significant $(F=0.276$; $p=0.842$ ) implying similarity in anxiety level among students regardless of year level.

Table 4 Anxiety level by classification or year level

\begin{tabular}{|c|c|c|c|c|c|}
\hline Anxiety Level & Freshman & Sophomore & Junior & Senior & Total \\
\hline $\begin{array}{l}\text { 1.0-1.9: Comfortably low test } \\
\text { anxiety }\end{array}$ & $\begin{array}{c}6 \\
(40.0)\end{array}$ & $\begin{array}{c}3 \\
(16.7)\end{array}$ & $\begin{array}{c}4 \\
(33.3)\end{array}$ & $\begin{array}{c}6 \\
(46.2)\end{array}$ & $\begin{array}{c}19 \\
(32.8)\end{array}$ \\
\hline $\begin{array}{l}\text { 2.0-2.5: Normal or average } \\
\text { test anxiety }\end{array}$ & $\begin{array}{c}4 \\
(26.7)\end{array}$ & $\begin{array}{c}9 \\
(50.0)\end{array}$ & $\begin{array}{c}4 \\
(33.3)\end{array}$ & $\begin{array}{c}2 \\
(15.4)\end{array}$ & $\begin{array}{c}19 \\
(32.8)\end{array}$ \\
\hline $\begin{array}{l}\text { 2.6-2.9: High normal test } \\
\text { anxiety }\end{array}$ & $\begin{array}{c}2 \\
(13.3)\end{array}$ & $\begin{array}{c}1 \\
(5.6)\end{array}$ & $\begin{array}{c}2 \\
(16.7)\end{array}$ & $\begin{array}{c}2 \\
(15.4)\end{array}$ & $\begin{array}{c}7 \\
(12.1)\end{array}$ \\
\hline $\begin{array}{l}\text { 3.0-3.4: Moderately high } \\
\text { anxiety }\end{array}$ & $\begin{array}{c}1 \\
(6.7)\end{array}$ & $\begin{array}{c}2 \\
(11.1)\end{array}$ & $\begin{array}{c}1 \\
(8.3)\end{array}$ & $\begin{array}{c}2 \\
(15.4)\end{array}$ & $\begin{array}{c}6 \\
(10.3)\end{array}$ \\
\hline 3.5-3.9: High test anxiety & $\begin{array}{c}0 \\
(0)\end{array}$ & $\begin{array}{c}3 \\
(16.7)\end{array}$ & $\begin{array}{c}1 \\
(8.3)\end{array}$ & $\begin{array}{c}1 \\
(7.7)\end{array}$ & $\begin{array}{c}5 \\
(8.6)\end{array}$ \\
\hline $\begin{array}{l}\text { 4.0-5.0: Extremely high } \\
\text { anxiety }\end{array}$ & $\begin{array}{c}2 \\
(13.3)\end{array}$ & $\begin{array}{c}0 \\
(0)\end{array}$ & $\begin{array}{c}0 \\
(0)\end{array}$ & $\begin{array}{c}0 \\
(0)\end{array}$ & $\begin{array}{c}2 \\
(3.4)\end{array}$ \\
\hline Total & $\begin{array}{c}15 \\
(100.0)\end{array}$ & $\begin{array}{c}18 \\
(100.0)\end{array}$ & $\begin{array}{c}12 \\
(100.0)\end{array}$ & $\begin{array}{c}13 \\
(100.0)\end{array}$ & $\begin{array}{c}58 \\
(100.0)\end{array}$ \\
\hline
\end{tabular}


Selected Personal Factors, Test Anxiety and Academic Performance of BAMS Online Learners

Differences in mean academic performance between gender and across student classification were analysed by employing $t$-test and analysis of variance (ANOVA), as appropriate (Tables 5 to 7 ). Results revealed that there are no significant differences in academic performance across age group $(F=2.009, p=0.124)$, between female and male BAMS distance learners $(t=0.135, p=0.893)$, and across classification or level of student academic standing $(F=1.509, p=0.223)$.

Table 5 ANOVA of age group on GWA

\begin{tabular}{lcccc}
\hline Age Group & $n$ & Mean & F & $p$-value \\
\hline $16-25$ & 30 & 2.41 & & \\
$26-35$ & 21 & 1.96 & & \\
$36-45$ & 3 & 2.13 & 2.009 & 0.124 \\
46 and above & 4 & 2.38 & & \\
\hline
\end{tabular}

Table 6 t-test of gender on GWA

\begin{tabular}{lcccc}
\hline Gender & $n$ & Mean & $t$ & $p$-value \\
\hline Female & 35 & 2.24 & & \\
Male & 23 & 2.22 & 0.135 & 0.893 \\
\hline
\end{tabular}

Table 7 ANOVA of classification on GWA

\begin{tabular}{lcccc}
\hline Classification & $n$ & Mean & $F$ & $p$-value \\
\hline Freshman & 15 & 2.53 & 1.509 & 0.223 \\
Sophomore & 18 & 2.14 & & \\
Junior & 12 & 2.19 & & \\
Senior & 13 & 2.05 & & \\
\hline
\end{tabular}

The results imply that while there are differences in mean values, the variations between or across categories are not large enough to bring about statistical significant differences. For instance, those who belonged to the youngest age group of 16 to 25 years had the lowest academic performance with mean GWA of 2.41 while those in the next older age group of 26 to 
35 years obtained the highest mean GWA of 1.96 (Table 5) which indicates satisfactory to good performance of BAMS learners following the grading system being used by the UP Open University. Meanwhile, mean GWA of female students is 2.24 as against 2.22 for male students (Table 6) which reflects minimal difference in academic performance between male and female respondents. Finally, by classification, Senior students have the best performance with mean GWA of 2.05 followed by Sophomores (2.14) then Juniors (2.19) and Freshmen (2.53). It can be observed that in all instances, the mean GWAs are quite close across age groups, between gender, and across year levels of BAMS online learners.

Meanwhile, relationships between variables measured at the interval level were determined using Pearson Product Moment Correlation (Table 8). It has been found that age of BAMS online learners has a significant, negative relationship with test anxiety score $(r=-0.32, p=0.02)$. This implies that older students have lower test anxiety level or that older BAMS learners had higher confidence level in their online studies. This is supported by the earlier results shown in Table 4 which revealed that more Senior students fall within the 'comfortably low test anxiety' level compared with the other year levels. Moreover, anxiety score has positive and highly significant relationship with academic performance measured in terms of general weighted average $(r=0.47, p=0.00)$. This means that students with low anxiety score or those with low level of anxiety performed better in class or have better academic performance. Meanwhile, age of BAMS distance learners is not significantly related with academic performance $(r=-0.18$, $p=0.19)$. This is supported by the earlier results found in Table 5 which shows that there is no significance difference in academic performance across age groups.

Table 8 Relationship between age, anxiety level and academic performance (GWA)

\begin{tabular}{lcc}
\hline Selected variables & GWA & Anxiety score \\
\hline Age & -0.18 & $-0.32^{*}$ \\
& $(p=0.19)$ & $(p=0.02)$ \\
GWA & & $0.47^{* *}$ \\
& & $(p=0.00)$ \\
\hline
\end{tabular}

Note: * significant at $0.05 ; * *$ significant at 0.01 


\section{Conclusions and Recommendations}

The present study sought to determine the relationship of test anxiety and selected personal factors with academic performance of Bachelor of Arts in Multimedia Studies (BAMS) online learners of the UP Open University. The profile of the students was described in terms of selected personal factors such as age, gender and classification. Analysis of student profile indicates that the UP Open University BAMS online learners generally belonged to the youngest age bracket of 16-25 years and were mostly female. The level of test anxiety by age group shows that majority of those who belonged to the youngest age group of 16 to 25 years are within the 'normal or average test anxiety' level.

Meanwhile, results on analysis by gender specify that most females had 'comfortably low test anxiety' while the majority of the male respondents belonged to the 'normal or average test anxiety' category. Across classification or year level of students, results show that the greatest percentage of Senior students had 'comfortably low test anxiety' level. Overall, these results imply that Senior students or those who had longer experience as distance learners exhibited lower test anxiety level as compared with the rest of the students. However, further analysis using appropriate statistical tools shows that the difference in test anxiety level by gender and student classification or year level were not significant implying similarity in the level of test anxiety among online learners regardless of age, gender and year level.

As to academic performance, while Senior students perform best in terms of their General Weighted Average (GWA), statistical analysis reveals that there are no significant differences in mean academic performance across classification or year level. Similar result was also found between gender groups. While there are differences in mean values, the variations between or across categories are not large enough to bring about significant differences implying that academic performance does not vary so much by gender and year level of online learners.

Using Pearson Product Moment Correlation, it has been found that age of BAMS distance learners has a significant negative relationship with test anxiety score which implies that older students have lower test anxiety level. 
Moreover, test anxiety score has positive and highly significant relationship with academic performance measured in terms of general weighted average. Specifically, students with low level of anxiety perform better in class or have better academic performance. This is accordance with the study of Khalid and Hasan (2009) wherein undergraduate students with high academic achievement have low test anxiety scores. Finally, age of BAMS distance learners is not significantly related with academic performance indicating that academic performance of online learners is similar regardless of age. This result is supported by an earlier finding which suggests that academic performance does not vary significantly across year level.

Based on the findings of the study, the following recommendations are put forward:

1. With findings that anxiety score has highly significant relationship with academic performance, UP Open University should be aware of students' test anxiety level before the start of their studies to help them cope with the distance mode of study. This can be done through organised training programs, proper guidance counseling and appropriate student support strategies. Possible strategies such as online one-on-one counseling sessions and similar intervention programs can be employed. These will help the students on how to prepare and take their exams or tests and eventually become successful online leaners.

2. Although the UP Open University has strong student support programs, such as online registration, online examinations, and technical support, it is further recommended that a guidance and counseling services office or unit be created. This unit will formulate programs and strategies to address the anxiety and possible stress levels of students. Initially, a Coordinator for Guidance and Counseling Services can be identified but this may later be elevated to a Director position with its own staff under the Office of the Vice Chancellor for Academic Affairs.

3. The proposed guidance and counseling unit should also conduct studies into the causes of test anxiety as well as design programs of addressing various study concerns. Other psychological needs of online learners should likewise be the concern of this unit or office. 


\section{References}

Alip, A. 2002. Student's satisfaction with UPOU support services: Implications for distance education and educational technology. Unpublished diss. University of the Philippines Open University, Los Banos, Laguna.

American Test Anxieties Association website. http://www.amtaa.org/scales.html (accessed 24 July 2014).

BAMS program proposal version 8.3. 2007. Approved by the UPOU University Council and the UP Board of Regents.

Bandalaria, M. 2001. Effects of distance learner performance of the University of the Philippines Open University communication system. Unpublished diss. University of the Philippines Open University, Los Banos, Laguna.

Biner, P. M., R. Dean and A. Mellinger. 1994. Factors underlying distance learner satisfaction with televised college-level course. The American Journal of Distance Education 8(1): 60-71. https://doi.org/10.1080/08923649409526845

Biner, P. M., M. Summers, R. Dean, M. Bink, J. Anderson and B. Gelder. 1996. Student satisfaction with interactive telecourses as a function of demographic variables and prior telecourse experience. Distance Education: An International Journal 17(1): 33-43. https://doi.org/10.1080/0158791960170104

Bonito, S. R. 2013. Motivation factors in Distance Education. International Journal of Social, Behavioral, Educational, Economic, Business and Industrial Engineering 7(2): 458-460.

Boston, W., P. Ice and A. Gibson. 2012. Comprehensive assessment of student retention in online programmes. Online Journal of Distance Learning Administration 14(1).

Cassady, J. C. and R. E. Johnson. 2002. Cognitive text anxiety and academic performance. Contemporary Educational Psychology 27(2): 270-295. https://doi.org/10.1006/ ceps.2001.1094

Chapell, M., Z. Blanding, M. Takahashi, M. Silverstein, B. Newmann, A. Gubi and N. McCann. 2005. Text anxiety and academic performance in undergraduate and graduate schools. Journal of Educational Psychology 97(2): 268-274. https://doi. org/10.1037/0022-0663.97.2.268

Driscoll, R. 2004. Westside text anxiety scale validation. American Test Anxiety Association. http://files.eric.ed.gov/fulltext/ED495968.pdf.

Driscoll, R., B. Holt and L. Hunter. 2005. Accelerated desensitization and adaptive attitudes interventions and test gains with academic probation students. ERIC 10: 13.

Dutke, S. and J. Stober. 2001. Test anxiety, working memory, and cognitive performance: supportive effects of sequential demands. Cognition and Emotion 15(2001): 381389. https://doi.org/10.1080/02699930125922

Flor, A. 1995. Broadcast-based distance learning systems. Institute of Development Communication.

Flor A., M. Bandalaria, M. Jarmin, M. E. Sibal and E. Amoloza. 2009. The changing profile of distance learners. Unpublished article. 2-4. 
Garrison, D. R. and D. Shale. 1987. Mapping the boundaries of distance education: Problems in defining the field. American Journal of Distance Education 1(1): 7-13. https://doi.org/10.1080/08923648709526567

Hill, K. and A. Wigfield. 1984. Test anxiety. A major educational problem and what can be done about it. Elementary School Journal 85:105-126. https://doi. org/10.1086/461395

Hembree, R. 1988. Correlates, causes, effects and treatment of test anxiety. Review of Educational Research 58: 47-77. https://doi.org/10.3102/00346543058001047

Jarmin, M. 2006. Communication and learner variables associated with satisfaction and competency of students on distance education at the University of the Philippines Open University. Unpublished thesis.

Khalid, R. and S. S. Hasan. 2009. Test anxiety in high and low achievers. Pakistan Journal of Psychological Research 24(3-4).

Kaye, A. 1981. Origins and structures. In Distance teaching for higher and adult education, eds. A. Kaye and G. Rumble, 32-47. London: Croom Helm in association with the Open University Press.

Keegan, D. 1990. Foundations of distance education. 2nd ed. 20-41. London: Routledge.

Lee, J. F. 1999. Clashes in L2 reading: Research versus practice and readers' misconceptions. In Affect in foreign language and second language learning: a practical guide to creating a low-anxiety classroom atmosphere, ed. D. J. Young, 49-63. New York: McGraw-Hill.

Moore, M. and G. Kearsley. 1996. Distance education: A system view. California: Wadsworth Publishing Company.

Nipper, S. 1989. Third generation distance learning and computer conferencing. In Mindweave: Communication, computers and distance education, eds. R. Mason and A. Kaye. Oxford: Pergamon.

Park, J-H. 2007. Factors related to learner dropout in online learning. Paper presented at the International Research Conference in the Americas of the Academy of Human Resources Development.

Peters, O. 1994. Otto Peters on distance education: The industrialization of teaching and learning, ed. D. Keegan. London: Routledge.

Perraton, H. 1988. A theory for distance education. In Distance education: International perspectives, eds. D. Stewart, D. Keegan and B. Holmberg, 34-45. New York: Routledge.

Qureshi, E., L. Morton and E. Antosz. 2002. An interesting profile-university students who take distance education courses show weaker motivation than on-campus students. Online Journal of Distance Learning Administration, State University of West Georgia, Distance Education Center. 5(4).

Rangecroft, M., P. Gilroy, P. Long and T. Tricker. 1999. What is important to distance education students? Open Learning Journal 14(1): 17-24. https://doi. org $/ 10.1080 / 0268051990140104$

Rana, R. A. and N. Mahmood. 2010. The relationship between test anxiety and academic achievement. Bulletin of Education and Research 32(2): 63-74.

Rosado, B. 2013. The effects of deep muscle relaxation and study skills training on test anxiety and academic performance. East Texas Baptist University. 
Sampson, N. 2003. Meeting the needs of distance learners. Language, Learning and Technology 3: 103-118.

Spielberger, C. D. and P. R. Vagg. 1995. Test anxiety: A transactional process. In Test anxiety: Theory, assessment and treatment, eds. C. D. Spielberger and P. R. Vagg, 3-14. Washington, DC: Taylor \& Francis.

Taylor, J. C. 1995. Distance education technologies: The fourth generation. Australian Journal of Educational Technology 11(2): 1-7. https://doi.org/10.14742/ajet.2072

UP Open University website. http://www2.upou.edu.ph/ (accessed 24 July 2014).

Wine, J. 1971. Test anxiety. The state of the art. New York, Plenum Press.

Wong, S. undated. Effects of mood induction on performance test anxiety. Unpublished diss. College of Liberal Arts and Science. Department of Psychology. University of Florida. http://www.honors.ufl.edu/apps/Thesis.aspx/Details/285 (accessed 24 July 2014).

WPI Academic Technology Centre. 2012. WPI teaching with technology collaboratory characteristics of distance learning students. http://www.wpi.edu/Academics/ ATC/Collaboratory/Teaching/student (21 March 2016).

Zeidner, M. 1990. Does test anxiety bias scholastic aptitude test performance by gender and sociocultural group? Journal of Personality Assessment 55: 145-160. https:// doi.org/10.1080/00223891.1990.9674054 https://doi.org/10.1207/s15327752jpa5501\&2_14

Zoller, U. and D. Ben-Chain. 1990. Gender differences in examination type, test anxiety, and academic achievement in college science: A case study. Science Education 74(6): 597-608. https://doi.org/10.1002/sce.3730740603 